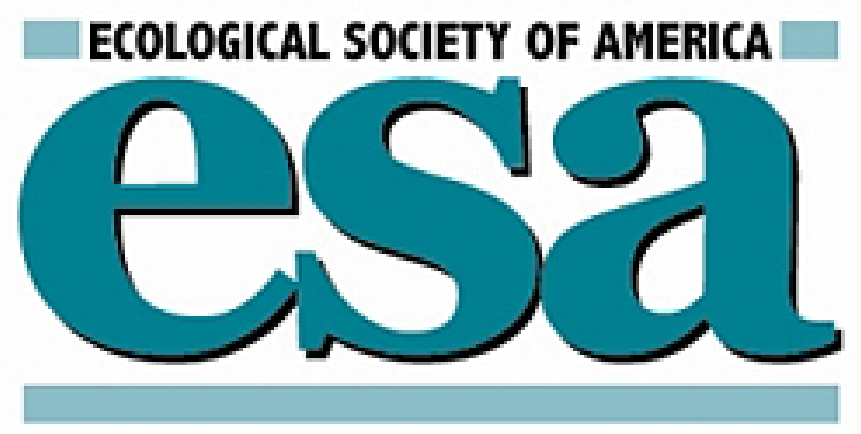

Homogenization Dynamics and Introduction Routes of Invasive Freshwater Fish in the Iberian Peninsula

Author(s): Miguel Clavero and Emili García-Berthou

Reviewed work(s):

Source: Ecological Applications, Vol. 16, No. 6 (Dec., 2006), pp. 2313-2324

Published by: Ecological Society of America

Stable URL: http://www.jstor.org/stable/40061960

Accessed: 06/02/2013 07:41

Your use of the JSTOR archive indicates your acceptance of the Terms \& Conditions of Use, available at http://www.jstor.org/page/info/about/policies/terms.jsp

JSTOR is a not-for-profit service that helps scholars, researchers, and students discover, use, and build upon a wide range of content in a trusted digital archive. We use information technology and tools to increase productivity and facilitate new forms of scholarship. For more information about JSTOR, please contact support@jstor.org. 


\title{
HOMOGENIZATION DYNAMICS AND INTRODUCTION ROUTES OF INVASIVE FRESHWATER FISH IN THE IBERIAN PENINSULA
}

\author{
Miguel Clavero ${ }^{1}$ and Emili García-Berthou \\ Institute of Aquatic Ecology, University of Girona, E-17071 Girona, Spain
}

\begin{abstract}
Nonnative invasive species are one of the main global threats to biodiversity. The understanding of the traits characterizing successful invaders and invasion-prone ecosystems is increasing, but our predictive ability is still limited. Quantitative information on biotic homogenization and particularly its temporal dynamics is even scarcer. We used freshwater fish distribution data in the Iberian Peninsula in four periods (before human intervention, 1991, 1995, and 2001) to assess the temporal dynamics of biotic homogenization among river basins. The percentage of introduced species among fish faunas has increased in recent times (from $41.8 \%$ in 1991 to $52.5 \%$ in 2001), leading to a clear increase in the similarity of community composition among basins. The mean Jaccard's index increase (a measure of biotic homogenization) from the pristine situation to the present (17.1\%) was similar to that for Californian fish but higher than for other studies. However, biotic homogenization was found to be a temporally dynamic process, with finer temporal grain analyses detecting transient stages of biotic differentiation. Introduced species assemblages were spatially structured along a latitudinal gradient in the Iberian Peninsula, with species related to sport fishing being characteristic of northern basins. Although the comparison of fish distributions in the Iberian Peninsula and France showed significant and generalized biotic homogenization, nonnative assemblages of northeastern Iberian basins were more similar to those of France than to those of the rest of the Iberian Peninsula, indicating a main introduction route. Species introduced to the Iberian Peninsula tended to be mainly piscivores or widely introduced species that previously had been introduced to France. Our results indicate that the simultaneous analysis of the spatial distribution of introduced assemblages (excluding native species that reflect other biogeographical patterns) and their specific traits can be an effective tool to detect introduction and invasion routes and to predict future invaders from donor regions.
\end{abstract}

Key words: biological invasions; biotic homogenization; introduced fish; invasive species.

\section{INTRODUCTION}

The establishment and spread of nonnative invasive species is one of the main global threats to biodiversity and a leading cause of animal extinctions (Vitousek et al. 1997, Clavero and Garcia-Berthou 2005). Biologists have long noticed that certain species colonize new territories due to human activities (Elton 1958), and there is a considerable amount of knowledge about the impacts of these invaders on native biotas (e.g., Williamson 1996). The consequences of biological invasions have also been gaining social relevance in recent times (Ehrlich and Ehrlich 1992, Mack et al. 2000). There is an urgent need to improve our understanding of biological invasions in order to control future invasions and predict and reduce their future effects (Shea and Chesson 2002). This implies the need for quantitative analyses of the processes and mechanisms involved in biological invasions (e.g., character-

Manuscript received 14 December 2005; revised 31 March 2006; accepted 27 April 2006. Corresponding Editor: T. E. Essington.

1E-mail: miguel.clavero@udg.es ization of successful invaders, identification of invasion pathways) and of the large-scale biotic changes following them, i.e., biotic homogenization (Mack et al. 2000, Lockwood and McKinney 2001, Ruiz and Carlton 2003).

Biotic homogenization is the ecological process by which formerly disparate biotas lose biological distinctiveness at any level of organization, including their genetic, taxonomic, and functional characteristics (Olden and Rooney 2006). It often involves the establishment of globally spread nonnative species and the extinction of endemic species (McKinney and Lockwood 1999, Rahel 2000). However, other processes regarding species introductions and extirpations and the identity of these species may be involved (Olden and Poff 2003). In fact, biotic homogenization is only one of the possible results of the human-facilitated transport of organisms across barriers and human-induced extinctions. Another possibility is that biotas become more different after human intervention than they were in their original state, i.e., biotic differentiation (Olden and Poff 2003). Biotic differentiation occurs, for example, when widely distributed species become extinct in certain regions or when different regions receive different nonnative species. 


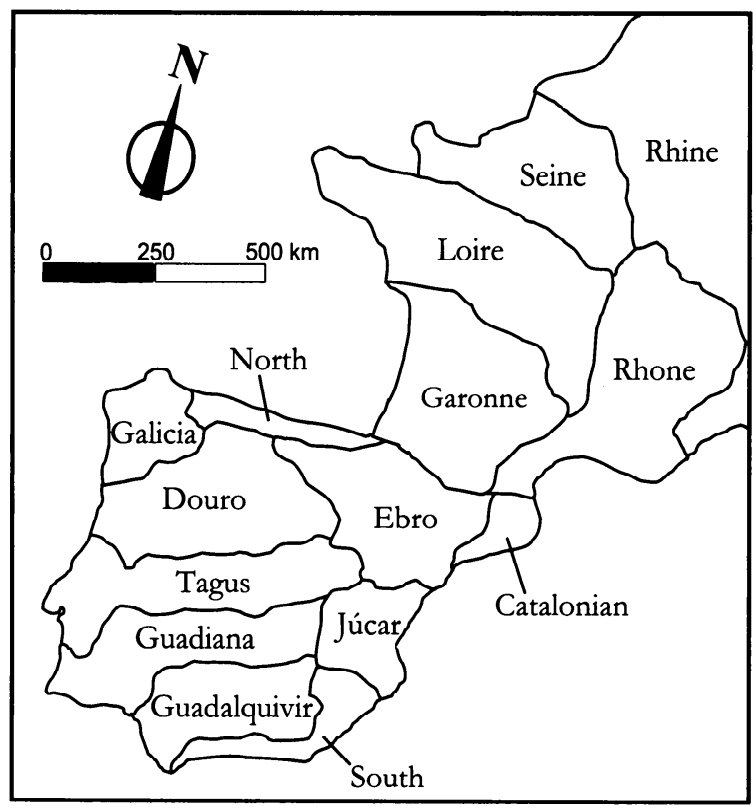

FIG. 1. Map of the 10 Iberian and the 5 French basins from which data on freshwater fish distributions were compiled.

The mechanisms involved in the changes in the similarity of communities over time have been shown to be strongly influenced by the spatial grain of observation (Marchetti et al. 2001, Olden and Poff 2004, Taylor 2004). However, the possible effects of temporal scale of observation on the perception of homogenization dynamics have not yet been quantitatively analyzed (but see discussion in Olden and Poff 2003). Most existing quantitative analyses of homogenization (e.g., Rahel 2000, Taylor 2004) have studied changes in the similarity among regions from the original pristine situation to the present. This results in a comparison of two static photographs of situations that may be separated by long periods, while the temporal dynamics of the homogenization process remain largely unknown. The analysis of these temporal dynamics requires data on species' distributions in intermediate situations. The inclusion of the time scale in homogenization analyses will certainly improve the current knowledge on the functioning of this process.

The identification of main invasion vectors and routes (Ricciardi and MacIsaac 2000, Garcia-Berthou et al. 2005) and the characteristics of successful invaders (Kolar and Lodge 2001, Marchetti et al. 2004b, Alcaraz et al. 2005) are key elements to increase the predictive ability of invasion biology. Taxonomy, human use, and previous history of invasions have been proposed as effective indicators to predict invasion success among freshwater fish (Alcaraz et al. 2005). Nevertheless, these analyses often fail to explicitly consider the spatial configuration of regions under analysis. This is especially important when dealing with strictly freshwater organisms, which are often dependent on human transport, not only to arrive at a certain region, but also to spread among different watersheds within that region. A simultaneous characterization of nonnative species' distribution patterns and human uses might be used to identify introduction routes and possible future invaders. Moreover, accounting for the spatial situation of different subregions (e.g., watersheds) in relation to donor areas would allow more reliable predictions of future invasions, providing information on invaders' identity, predicted place of arrival, and the possible subsequent expansion process.

We analyzed the temporal and spatial dynamics of invasion and biotic homogenization in freshwater fish communities using data from the Iberian Peninsula as a case study. The Iberian native freshwater fish fauna is greatly isolated from that of Central Europe, features a large proportion of endemic species (Doadrio 2001), and is distributed throughout a complex network of drainages that can be grouped in independent regions (e.g., Elvira 1995, Vargas et al. 1998). The introduction of nonnative species is a long-lasting and ongoing process in Iberian freshwaters, constituting one of the most important threats to native fish fauna (Garcia-Berthou and Moreno-Amich 2000, Elvira and Almodóvar 2001, Clavero et al. 2004). In this paper we use the data available on freshwater fish distribution in the Iberian Peninsula (henceforth IP) and France with three main objectives. The first objective is to analyze changes in community similarity under the conceptual framework of Olden and Poff (2003), providing the first quantitative approach to this phenomenon for freshwater fish outside North America. The fact that there have been no basinscale extinctions among nonmigratory freshwater fish in Iberian basins (Clavero et al. 2004) produces an invasion-only scenario to analyze the homogenization process. The second is to assess the effect of time scale on the perception of changes in community similarity, an aspect that has not yet been quantitatively investigated. The third objective is to illustrate that the spatial analysis of assemblages of introduced species permits the identification of introduction routes, and might help to predict and, it is hoped, prevent future invasions.

\section{METHODS}

\section{Data sources}

We compiled information on freshwater fish distribution in the Iberian Peninsula (IP) from three different sources, covering a 10-year period (Doadrio et al. 1991, Elvira 1995, Doadrio 2001). Doadrio (2001) refers to sampling carried out until 2000, and a similar delay between data gathering and publication might be expected for the other sources, but for simplicity we refer to the publication date. For the three dates, we recorded the presence of fish species in each of the 10 Iberian hydrographic units (henceforth simply "basins") defined by Elvira (1995) (Fig. 1). Following Copp et al. (2005), introduced species included translocated (species introduced from other basins within the IP) and foreign 
species (not native to the IP). To relate the presence of fish species in the IP to that in neighboring European basins, we used the maps provided by Keith and Allardi (2001) to compile the distribution of freshwater fish in continental France. French drainages were grouped in five major basins in which the presence of freshwater species was recorded (Fig. 1). Only resident freshwater species were included in the analyses. Migratory species were not included because the different data sources had heterogeneous criteria for including migratory or estuarine species in freshwater species lists. Moreover, the information available on the distribution of migratory/estuarine species is much more limited than that available for resident species. Mean latitude and longitude of each Iberian basin and of France (whole territory) were calculated as the means of their minimum and maximum values. The distance (in degrees) among all Iberian basin pairs and between each Iberian basin and France was then calculated from mean latitude and longitude values. Date of introduction was recorded for species introduced to the IP (from Elvira and Almodóvar 2001) and France (from Bruslé and Quignard 2001, Keith and Allardi 2001).

Data from Doadrio et al. (1991) derive from an extensive survey covering $>140$ river stretches, which was complemented with a review of available information. Elvira (1995) is based on Doadrio et al. (1991), but updates it with published and unpublished records. Doadrio (2001) uses these previous works, also compiling information published after 1990 and results from extensive field surveys made from 1995 to 2000 (Ambrosio 2001). Since consecutive data sources are inclusive, it can be assumed that they included the most complete information on fish distribution available at their respective publication date. When a nonnative species was cited in a certain basin both in 1991 and 2001 , it was considered to be present there in 1995, even when it was not cited by Elvira (1995) (e.g., carp, Cyprinus carpio, in Galicia basin). Thus, possible homogenization patterns would not be caused by missing species' presence due to different sampling effort. Fish introductions are often unrecorded and detected late by ichthyologists, especially when, as in the IP since the 1960s, they are illegally performed (Elvira and Almodóvar 2001). Moreover, our aim was not absolute quantification but the statistical comparison of spatial and temporal patterns of freshwater fish invasion occurring over large areas.

From the Fishbase database (Froese and Pauly 2006) we recorded for each nonnative fish, the number of countries in which a species had been introduced (as a measure of the species' global invasion success), and, as variables related to the original geographic extent, the number of countries in which the species was native and the mean latitude and latitudinal range occupied. We also classified the different species as "piscivore," "game" (including species used as bait), and "aquarium" (excluding species reported to be used only in public aquariums). These categories were not mutually exclusive (in fact, all piscivores were also game species, though the contrary was not always true). These biological or human use categories are not direct indicators of introduction purposes or vectors (e.g., Marchetti et al. 2004a). However, real introduction vectors are difficult to establish in the IP for different reasons. First, as stated previously, recent introductions occurring in Spain have been illegally performed. Second, some species (e.g., pumpkinseed sunfish, Lepomis gibbosus) were first introduced in Lake Banyoles (Catalonian basin) as early as the 1910 s to "improve" wild stocks (García-Berthou and Moreno-Amich 2000, Elvira and Almodóvar 2001), and only in the last decades have expanded their ranges to other basins, often for unknown reasons. And third, since each new occurrence of a nonnative species in a certain basin implies an independent introduction event, multiple introduction purposes might be involved for a single species (which is especially hard to detect due to the illegal character of these introductions) (see Marchetti et al. 2006). We therefore used biological traits and general human uses as surrogates of introduction purposes (c.g., the fact that a nonnative species is classified as a piscivore or game fish is related to sport fishing purposes in its introduction and interbasin expansion).

To assess possible relationships between development of sport fishing and nonnative fish occurrence, we recorded the number of fishing licenses per 1000 inhabitants and the total amount of money generated by fishing licenses in each of the 45 continental Spanish provinces during 2002 (MAPA 2003). Since political and hydrological borders do not coincide, these data were not available for basins, so we calculated the mean latitude of each province.

\section{Statistical analyses}

We calculated the percentage of nonnative species in the IP for each basin and period. The influence of both factors on the percentage of nonnative species was analyzed through a two-way ANOVA without replication. The homogenization process was assessed through changes in similarity (Jaccard's coefficient, expressed as a percentage) among basins (Rahel 2000, Olden and Poff 2003). We calculated the Jaccard's index of similarity for each of the 45 pairwise comparisons of the 10 main Iberian basins in four different periods: original (including only native species), 1991, 1995, and 2001. Homogenization-differentiation was estimated from differences in community similarity (Jaccard's index) of each pair of basins (hereafter $\Delta \mathrm{CS}$ ). We compared present (i.e., 2001) and original situations, but also made the original-1991, 1991-1995, and 1995-2001 comparisons. We plotted $\triangle \mathrm{CS}$ against initial community similarity (original, 1991, or 1995) to relate similarity changes with the two invasion-only scenarios proposed by Olden and Poff (2003). 
TABLE 1. Distribution of introduced freshwater species in the Iberian Peninsula.

\begin{tabular}{|c|c|c|c|c|c|c|c|c|c|c|}
\hline \multirow[b]{2}{*}{ Origin } & \multirow[b]{2}{*}{ Common name } & \multirow[b]{2}{*}{ Scientific name } & \multirow[b]{2}{*}{ Code } & \multirow[b]{2}{*}{ Family } & \multicolumn{6}{|c|}{ Basin codes } \\
\hline & & & & & No & $\mathrm{Ga}$ & Do & $\mathrm{Ta}$ & Gn & $\mathrm{Gr}$ \\
\hline \multirow[t]{23}{*}{ Foreign species } & Coho salmon & Oncorhynchus kisutch & 1 & Salmonidae & 0 & 0 & + & 0 & 0 & 0 \\
\hline & Rainbow trout & Oncorhynchus mykiss & 2 & Salmonidae & + & + & + & + & 0 & + \\
\hline & Brook trout & Salvelinus fontinalis & 3 & Salmonidae & + & 0 & + & + & 0 & 0 \\
\hline & Danube salmon & Hucho hucho & 4 & Salmonidae & 0 & 0 & + & 0 & 0 & 0 \\
\hline & Northern pike & Esox lucius & 5 & Esocidae & + & + & + & + & + & + \\
\hline & Goldfish & Carassius auratus & 6 & Cyprinidae & + & + & + & + & + & + \\
\hline & White bream & Abramis bjoerkna & 7 & Cyprinidae & 0 & 0 & 0 & 0 & 0 & 0 \\
\hline & Bleak & Alburnus alburnus & 8 & Cyprinidae & + & 0 & 0 & 0 & 0 & 0 \\
\hline & Carp & Cyprinus carpio & 9 & Cyprinidae & + & + & + & + & + & + \\
\hline & Roach & Rutilus rutilus & 10 & Cyprinidae & 0 & 0 & 0 & 0 & 0 & 0 \\
\hline & Rudd & Scardinius erythrophthalmus & 11 & Cyprinidae & 0 & 0 & 0 & 0 & + & 0 \\
\hline & Mediterranean toothcarp & Aphanius fasciatus & 12 & Cyprinodontidae & 0 & 0 & 0 & 0 & 0 & 0 \\
\hline & Mummichog & Fundulus heteroclitus & 13 & Fundulidae & 0 & 0 & 0 & 0 & + & + \\
\hline & Eastern mosquitofish & Gambusia holbrooki & 14 & Poeciliidae & 0 & 0 & + & + & + & + \\
\hline & Guppy & Poecilia reticulata & 15 & Poeciliidae & 0 & 0 & 0 & 0 & 0 & 0 \\
\hline & Chameleon cichlid & Herichthys facetum & 16 & Cichlidae & 0 & 0 & 0 & 0 & + & 0 \\
\hline & Pumpkinseed sunfish & Lepomis gibbosus & 17 & Centrarchidae & 0 & 0 & + & + & + & + \\
\hline & Largemouth bass & Micropterus salmoides & 18 & Centrarchidae & + & + & + & + & + & + \\
\hline & Perch & Perca fluviatilis & 19 & Percidae & 0 & 0 & 0 & 0 & 0 & 0 \\
\hline & Zander & Sander lucioperca & 20 & Percidae & 0 & 0 & + & + & 0 & 0 \\
\hline & Black bullhead & Ameiurus melas & 21 & Ictaluridae & 0 & 0 & 0 & + & 0 & 0 \\
\hline & Channel catfish & Ictalurus punctatus & 22 & Ictaluridae & 0 & 0 & 0 & 0 & 0 & 0 \\
\hline & European catfish & Silurus glanis & 23 & Siluridae & 0 & 0 & 0 & + & 0 & 0 \\
\hline \multirow[t]{10}{*}{ Translocated species } & Brown trout & Salmo trutta & 24 & Salmonidae & $\mathbf{N}$ & $\mathrm{N}$ & $\mathrm{N}$ & $\mathrm{N}$ & + & $\mathrm{N}$ \\
\hline & Ebro barbel & Barbus graellsii & 25 & Cyprinidae & $\mathrm{N}$ & 0 & 0 & 0 & 0 & 0 \\
\hline & Tagus nase & Chondrostoma polylepis & 26 & Cyprinidae & 0 & 0 & 0 & $\mathbf{N}$ & 0 & 0 \\
\hline & Ebro nase & Chondrostoma miegii & 27 & Cyprinidae & $\mathbf{N}$ & 0 & 0 & + & 0 & 0 \\
\hline & Bermejuela nase & Chondrostoma arcasii & 28 & Cyprinidae & 0 & $\mathrm{~N}$ & $\mathrm{~N}$ & $\mathrm{~N}$ & + & 0 \\
\hline & Iberian gudgeon & Gobio lozanoi & 29 & Cyprinidae & $\mathbf{N}$ & + & + & + & + & + \\
\hline & Minnow & Phoxinus phoxinus & 30 & Cyprinidae & 0 & $\mathrm{~N}$ & + & 0 & 0 & 0 \\
\hline & Calandino chub & Squalius alburnoides & 31 & Cyprinidae & 0 & 0 & $\mathbf{N}$ & $\mathrm{N}$ & $\mathrm{N}$ & $\mathrm{N}$ \\
\hline & Iberian loach & Cobitis paludica & 32 & Cobitidae & + & + & $\mathrm{N}$ & $\mathrm{N}$ & $\mathrm{N}$ & $\mathrm{N}$ \\
\hline & Stone loach & Barbatula barbatula & 33 & Balitoridae & $\mathbf{N}$ & 0 & + & 0 & 0 & 0 \\
\hline
\end{tabular}

Notes: Data are from Doadrio (2001) and Elvira and Almodóvar (2001). Basin codes: No, North; Ga, Galicia; Do, Douro; Ta, Tagus; Gn, Guadiana; Gr, Guadalquivir; So, South; Ju, Júcar; Eb, Ebro; Ca, Catalonian. A "+" symbol denotes presence as nonnative species, while " $N$ " denotes presence as native; 0 in cells simply means there are no data for that cell. The date of introduction is from Elvira and Almodóvar (2001). First recording basin is also shown (n.a., not available). Status in France: I, introduced; N, native; T, translocated native species; Abs, absent (from Keith and Allardi 2001).

Changes in the relationship between distance between pairs of basins and their similarity were assessed through one-way ANCOVA, using "distance" as covariate and "period" as factor. Homogeneity-of-slopes ANCOVA design was used to test changes in the slope of the distance-similarity relationship, through the significance of the interaction term (Garcia-Berthou 2001). We also assessed the similarity changes between Iberian and French basins, comparing data from 2001 (including nonnatives) and the original fish distribution (i.e., with only natives). For these two periods we also analyzed the number of species shared by each Iberian basin and France (pooling data for the five French basins). The change in mean similarity between Iberian and French basins and the change in fish species shared between France and Iberian basins was analyzed using ANCOVA with distance as the covariate.

Correspondence analysis (CA) was used to summarize information on nonnative species distribution in Iberian basins in 2001 (Table 1). CA is similar to principal component analysis but performs better with matrices of abundance or presence data with many zeros, and is therefore preferred for community ecology (Jongman et al. 1995). The first axes (dimensions) produced by the $\mathrm{CA}$ explain most of the variation in the original data, with close scores in the CA plot corresponding to similar entities (either species or basins). The possible relationships between CA axes and variables characterizing fish species and basins were studied through correlation analysis and one-way ANOVAs.

In order to detect possible introduction routes among French and Iberian basins, a cluster analysis was performed on the distribution of those species that are recorded as nonnatives in the IP. Jaccard's index of similarity and average linkage were used in this analysis. To analyze the main characteristics of the nonnative species present in France and IP we made three groups of species: (1) species recorded only in France; (2) species recorded only in IP; and (3) species recorded in both regions. Differences among the three groups were analyzed by one-way ANOVAs for continuous variables and independence tests ( $G$ statistics with exact tests) for categorical variables. 
TABLE 1. Extended.

\begin{tabular}{|c|c|c|c|c|c|c|}
\hline \multicolumn{4}{|c|}{ Basin codes } & \multirow{2}{*}{$\begin{array}{c}\text { Date of } \\
\text { introduction }\end{array}$} & \multirow{2}{*}{$\begin{array}{c}\text { First } \\
\text { recorded in }\end{array}$} & \multirow{2}{*}{$\begin{array}{c}\text { Status in } \\
\text { France }\end{array}$} \\
\hline So & $\mathrm{Ju}$ & $\mathrm{Eb}$ & $\mathrm{Ca}$ & & & \\
\hline 0 & 0 & 0 & 0 & 1983 & Do & I \\
\hline+ & + & + & + & 1890 & n.a. & I \\
\hline 0 & 0 & + & 0 & 1890 & n.a. & I \\
\hline 0 & 0 & 0 & 0 & 1968 & Do & I \\
\hline+ & + & + & + & 1949 & n.a. & $N(T)$ \\
\hline+ & + & + & + & 1650 & n.a. & I \\
\hline+ & + & 0 & 0 & 1995 & $\mathrm{~Eb}$ & $\mathrm{~N}$ \\
\hline 0 & + & + & 0 & 1992 & $\mathrm{~Eb}$ & $\mathbf{N}$ \\
\hline+ & + & + & + & 1650 & n.a. & I \\
\hline 0 & 0 & + & + & 1910 & $\mathrm{Ca}$ & $\mathbf{N}$ \\
\hline 0 & 0 & + & + & 1910 & $\mathrm{Ca}$ & $\mathrm{N}$ \\
\hline 0 & 0 & + & 0 & $1997^{\circ}$ & $\mathrm{Eb}$ & Abs \\
\hline 0 & 0 & 0 & 0 & 1970 & $\mathrm{Gr}$ & Abs \\
\hline+ & + & + & + & 1921 & n.a. & I \\
\hline 0 & + & 0 & 0 & 2000 & $\mathrm{Ju}$ & Abs \\
\hline+ & 0 & 0 & 0 & 1985 & $\mathrm{Gn}$ & Abs \\
\hline 0 & + & + & + & 1910 & $\mathrm{Ca}$ & I \\
\hline+ & + & + & + & 1955 & n.a. & I \\
\hline 0 & 0 & + & + & 1970 & $\mathrm{Ca}$ & $\mathrm{N}(\mathrm{T})$ \\
\hline 0 & + & + & 0 & 1974 & $\mathrm{Ca}$ & I \\
\hline 0 & + & + & + & 1910 & $\mathrm{Ca}$ & I \\
\hline 0 & 0 & + & 0 & 1995 & $\mathrm{~Eb}$ & Abs \\
\hline 0 & 0 & + & 0 & 1974 & $\mathrm{~Eb}$ & I \\
\hline $\mathbf{N}$ & $\mathrm{N}$ & $\mathbf{N}$ & $\mathbf{N}$ & & & \\
\hline 0 & 0 & $\mathrm{~N}$ & + & & & \\
\hline+ & + & 0 & 0 & & & \\
\hline 0 & 0 & $\mathbf{N}$ & + & & & \\
\hline 0 & $N$ & $\mathbf{N}$ & $\mathbf{N}$ & & & \\
\hline+ & + & $\mathbf{N}$ & + & & & \\
\hline 0 & 0 & $\mathbf{N}$ & $\mathrm{N}$ & & & \\
\hline 0 & + & 0 & 0 & & & \\
\hline 0 & $\mathrm{~N}$ & $\mathbf{N}$ & + & & & \\
\hline 0 & 0 & $\mathrm{~N}$ & 0 & & & \\
\hline
\end{tabular}

Quantitative variables were $\log _{10}$ or $\log _{10}(x+1)$ transformed prior to analysis because assumptions of parametric statistics were improved. All statistical analyses were computed with SPSS version 11.5 (SPSS 2002).

\section{RESULTS}

\section{Invasion and homogenization dynamics}

For a total of 60 nonmigratory freshwater fish species recorded in the IP, 23 (38.3\%) were of foreign origin, while 10 others were Iberian species that had been translocated to basins where they were not native (Table 1). There was a highly significant relationship between the numbers of native and introduced foreign species present in the basins $(r=0.90, n=10, P<0.001)$, while no relationship was observed between the numbers of native and translocated species $(r=-0.36, n=10, P=$ 0.31 ). There was a strong negative relationship between the date of introduction of foreign species and the number of basins where they are present (Spearman's $r_{\mathrm{s}}$ $=-0.73, n=23, P<0.001)$. This relationship shows that once a species has been introduced to the IP it tends to expand its range through introductions to new basins.

The percentage of introduced species in Iberian basins was significantly influenced both by the "period" $\left(F_{2,18}=\right.$ $18.8, P<0.001)$ and "basin" $\left(F_{9,18}=10.6, P<0.001\right)$ factors. In the 10-year period running from 1991 to 2001, the mean percentage of introduced species increased from $41.8 \%$ (range $23.1-54.5 \%$ ) to $52.5 \%$ (range 44.4-58.8\%) (Fig. 2). In 2001, 7 out of the 10 basins had more nonnative than native species and in three of them the percentage of nonnatives was $>58 \%$. The minimum percentage of introduced species recorded in 2001 was higher than the mean value observed in

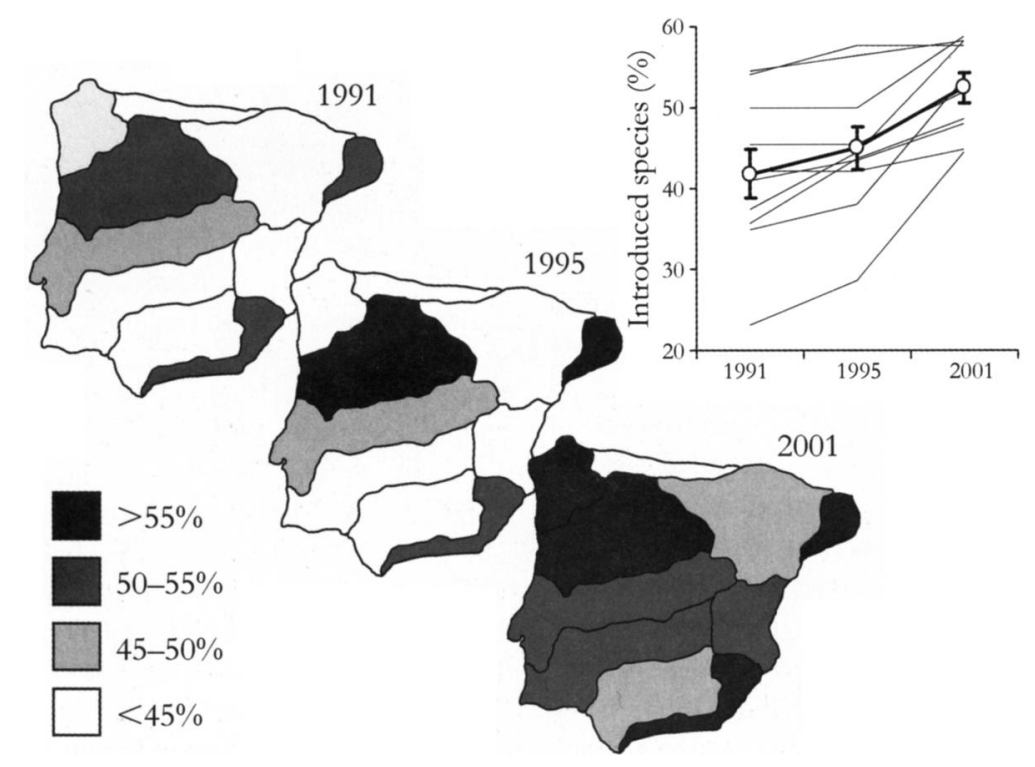

FIG. 2. Variation of the percentage of introduced species in Iberian basins between 1991 and 2001. In the graph, lines represent the variation in each basin, while the bold line and open circles represent the mean ( $\pm \mathrm{SE})$. 


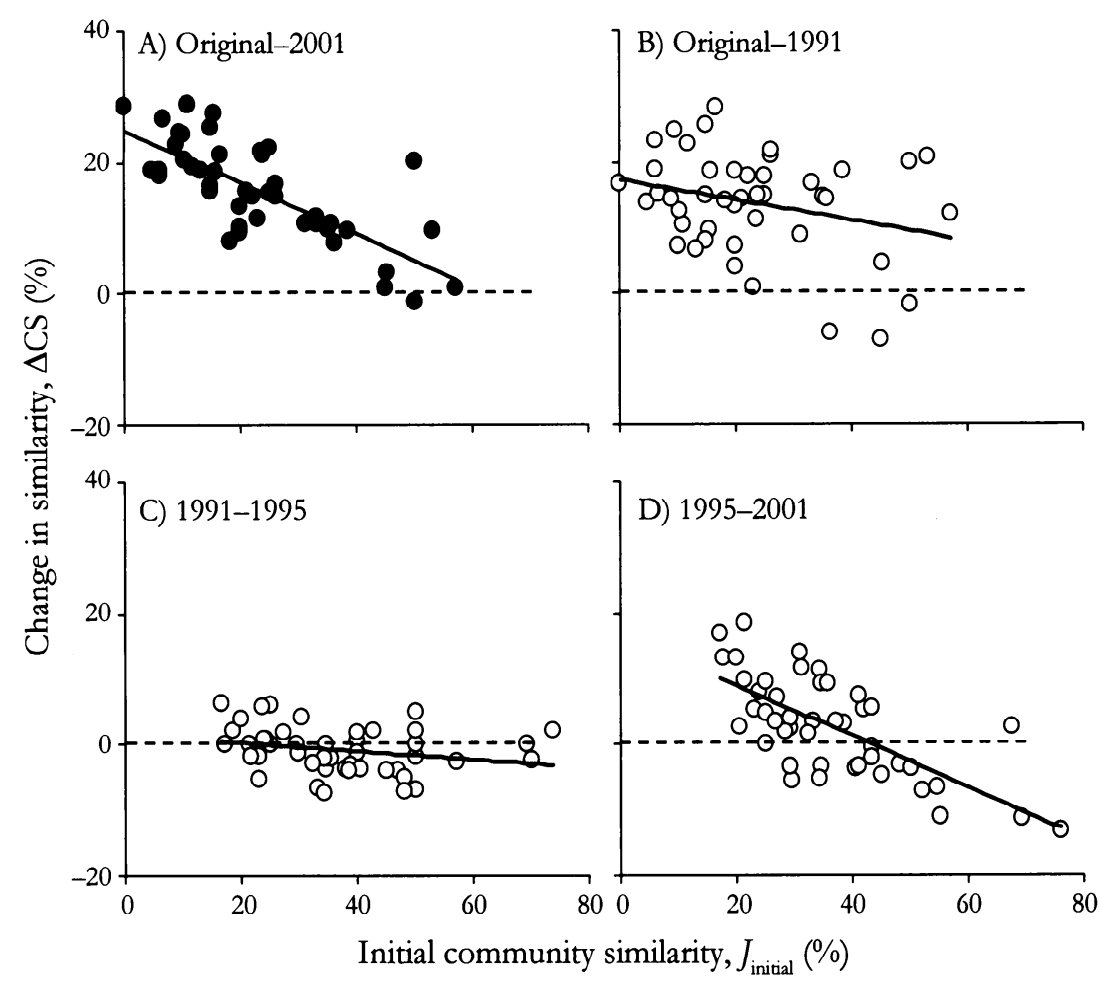

FIG. 3. Changes in similarity of freshwater fish fauna among 45 pairwise comparisons of 10 Iberian basins in relation to their original similarity values (following Olden and Poff 2004). Changes are shown between the original situation and that of 2001 (A) and for intermediate time periods (B, C, and D).

1991. The total number of introduced species in Iberian basins increased from 16 in 1991, to 22 in 1995, and 33 in 2001. In the same 10-year period (1991-2001), the sum of records of the different nonnative species in the 10 basins increased from 80 to 119 , exceeding the sum of records for native species (111).

The addition of nonnative species in Iberian basins has led to a clear homogenization of fish faunas (Fig. $3 \mathrm{~A})$. In the three periods analyzed, the Iberian basins had on average over $10 \%$ more species in common than in the original situation. However, this increase in faunal similarity was not gradual in time. In fact, the addition of 6 new species in 1995 resulted on average in a small reduction in similarity (i.e., differentiation) of Iberian fish faunas (Fig. 3C). With 11 new introduced species found in 2001, there was a wide range of responses among basins (Fig. 3D), including differentiation through recent additions of locally distributed species, and homogenization due to geographic spread of previously established species. In 1991, most introduced species were widely distributed, occupying a mean of 5.0 basins in the IP. In the following years the number of basins occupied per introduced species was reduced to 4.0 basins in 1995 and 3.6 basins in 2001 . However, the 16 introduced species recorded in 1991 had expanded their distribution in 2001 to occupy 5.6 basins on average.
As expected, there was a clear negative relationship in geographical distance between basins and their faunal similarity. The slopes of this relation were not statistically different among periods (period $\times$ distance, $F_{3,172}$ $=0.41, P=0.75)$, and once this interaction term had been removed from the model, both period $\left(F_{3,175}=\right.$ $18.3, P<0.001)$ and distance $\left(F_{1,175}=63.2, P<0.001\right)$ strongly influenced basin similarities.

\section{Introduction routes and prediction of future invasions}

Assemblages of introduced fish species within the IP were not homogeneous by 2001. A latitudinal gradient in the composition of assemblages was detected by means of the CA, with northern basins having significantly higher scores on the first CA axis $(r=0.70, n=10$, $P=0.02$ ) (Fig. 4). Characteristic species in southern basins included two American species (chameleon cichlid, Herichthys facetum and mummichog, Fundulus heteroclitus), and two translocated species widely distributed throughout the IP (brown trout, Salmo trutta and bermejuela nase, Chondrostoma arcasii). Northern basins were mainly characterized by the presence of several European species and large piscivores (e.g., European catfish, Silurus glanis and perch, Perca fluviatilis). Introduced species having more northern ranges also tended to have higher scores on the first CA axis $(r=0.31, n=31, P=0.08)$. The latitudinal gradient in introduced assemblages' composition was also related 

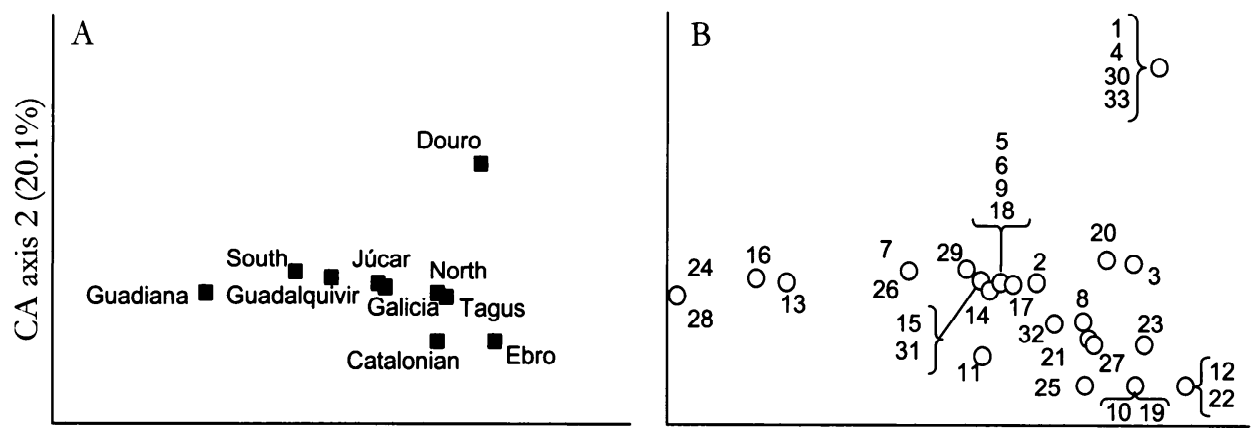

CA axis $1(20.9 \%)$
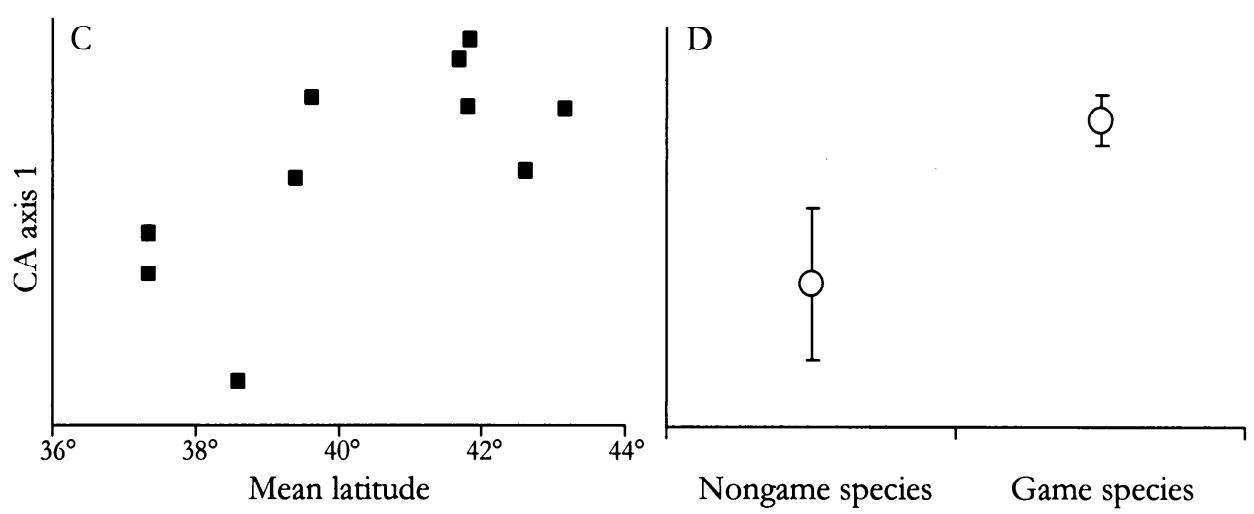

FIG. 4. Results of the correspondence analysis (CA) on the distribution of introduced freshwater fish species in Iberian basins: (A) basin scores; (B) species scores (codes are given in Table 1); (C) relation between mean latitude and scores on the first axis of the $\mathrm{CA}$ for the analyzed basins; and (D) mean $( \pm \mathrm{SE})$ scores on the first axis of the CA of game and nongame introduced species in Iberian basins.

to the use of introduced species in sport fishing, since game species had significantly higher scores along the latitudinal gradient defined by the first $\mathrm{CA}$ axis (i.e., were characteristic of northern basins) $\left(F_{1,31}=7.2, P=\right.$ $0.01)$. This relationship between latitude and sport fishing was also shown by the significant correlation between the amount of money spent on fishing licenses in Spanish provinces and their mean latitude $(r=0.53, n$ $=44, P<0.001)$. The second CA axis was mainly related to some introductions unique to the Douro River basin, including two salmonids and two translocated Iberian species (Fig. 4).

Between the original pristine situation and that recorded by 2001 there was a mean increase of $11.5 \%$ in Jaccard's coefficient between Iberian and French basins, an increase which is similar to that observed among Iberian basins. The similarity between a particular Iberian basin and the French ones depended significantly on the distance to France, both in the original and 2001 faunas (Fig. 5A). The slope of this relationship did not vary with time (period $\times$ distance, $F_{1,16}=0.02, P=0.89$ ), and there was a clear increase in the similarity of the Iberian and French basins in 2001 compared to the original situation (ANCOVA, $F_{1,17}=$ $35.7, P<0.001)$. The situation was somehow different when the number of species shared with France was considered. The slope of the relationship between this variable and distance to France was different between the original situation and 2001 (Fig. 5B), although significance was marginal (period $\times$ distance, $F_{1,16}=3.3$, $P=0.08$ ). This result means that until 2001, Iberian basins located nearer to France received more nonnative fish species coming from this country than basins located far from it. Cluster analysis demonstrated that the nonnative fish assemblages of northeastern Iberian basins (i.e., Ebro and Catalonia) were more similar to those in French basins than to nonnative fish assemblages in other Iberian basins (Fig. 5C), also highlighting an introduction route of fish species in the IP, from central Europe to northeastern Iberia. In fact, of the 16 introduced species for which first record location data were available, 11 were first cited in northeastern Iberian basins (Table 1).

There was a highly significant association between the presence of a nonnative species in the IP and its presence also as nonnative in France $(G=26.9, \mathrm{df}=2$, exact $P<$ 0.001 ). Despite the fact that France had more native (33) than introduced (28) species, 12 of the 23 introduced species recorded in the IP in 2001, as well as 3 recent introductions (see Table 2), were also species introduced to France. All introduced species were first introduced in France and later in the IP, with the exception of 

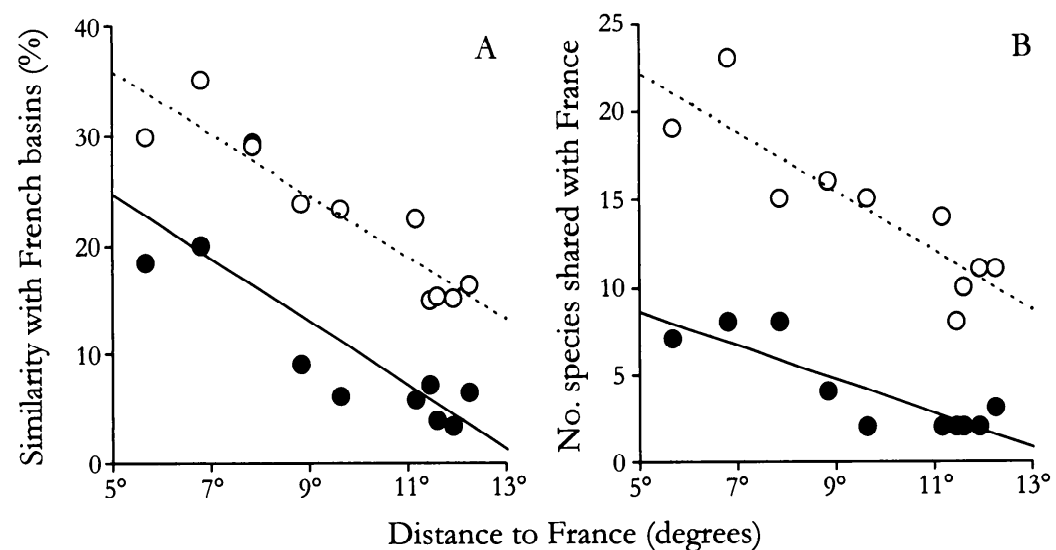

Distance to France (degrees)

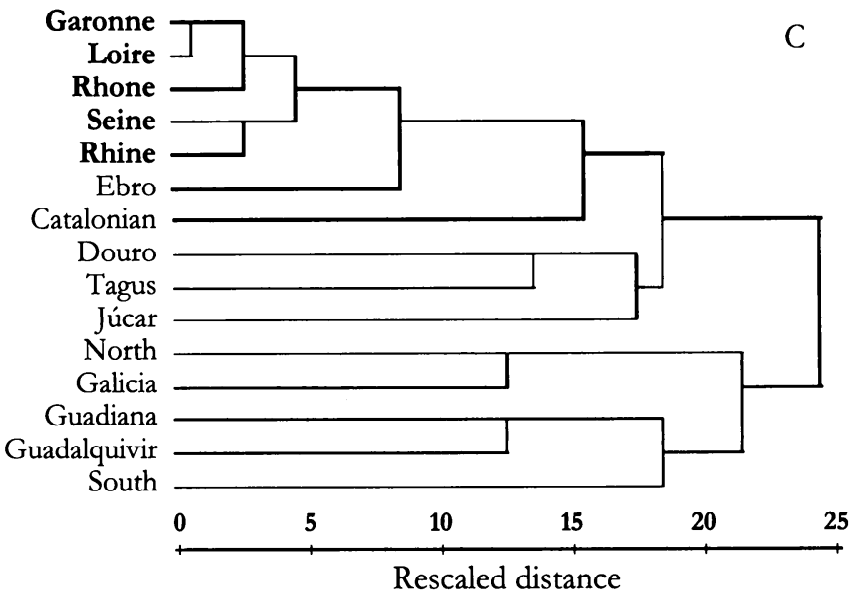

FIG. 5. Relationship between the distance to France of the 10 Iberian basins and: (A) their mean similarity (Jaccard's coefficient) with French basins in the original situation, i.e., considering only native species, (solid circles, solid line) and in 2001 (open circles, dotted line); (B) the number of fish species shared with French basins in the original situation (solid circles, solid line) and in 2001 (open circles, dotted line). (C) Cluster analysis (Jaccard's index and average linkage) of Iberian and French basins considering the presence of nonnative species recorded in the Iberian Peninsula. French basins are shown in boldface type. The distances in panel $\mathrm{C}$ are rescaled from the original similarities to fall into the range of 1 to 25; the ratio of these rescaled distances within the dendrogram is the same as that of the original similarities.

mosquitofish (Gambusia holbrooki), which was simultaneously introduced to both areas (Fig. 6). Even without considering ancient introductions (i.e., pre-1800s, see Table 1), there was a positive regression between the date of introduction to France and that to IP $\left(R^{2}=0.48\right.$, $P<0.01)$. The slope of this relationship $(b=0.69 \pm 0.2$ [mean $\pm \mathrm{sE}$ ] $)$ was significantly smaller than $1\left(t_{11}=4.35\right.$, $P<0.001$ ), showing that there has been a historical reduction in the time lag between a species' introduction to France and its subsequent introduction to IP. Regarding species introduced to the IP, France, or both areas, there was a significant overrepresentation of piscivore species among species present in both areas ( $G=11.0, \mathrm{df}=2$, exact $P=0.007)$. Nonnative species shared by France and the IP had been also introduced in a higher number of countries (37.2 countries on average) than species found only in France or only in the IP (13.5 and 6.4 countries, respectively) $\left(F_{2,52}=11.8, P<0.001\right)$.

\section{Discussion}

\section{Invasion and homogenization through time}

Freshwater fish fauna in the IP is experiencing a widespread and dynamic invasion process. As a mean, in 2001 Iberian river basins had more nonnative species than native ones, with the proportion of nonnative species showing a clearly growing progression. The number of fish species recorded as nonnatives in the different basins has doubled (from 16 to 33 species) in the 10-year period from 1991 to 2001 , and these nonnative species show a clear trend toward range expansion once they have been introduced.

The introduction of nonnative fish species in the IP has resulted in a clear biotic homogenization among basins, with Jaccard's index of similarity increasing 17.1 $\pm 8.0 \%$ (mean $\pm \mathrm{SD}$ ) from the original pristine situation to that of 2001. This result is similar to that obtained by Marchetti et al. (2001) for Californian zoogeographic provinces $(20.3 \%)$, but is clearly higher than the results 
TABle 2. Nonnative species introduced to France and not recorded in the Iberian Peninsula by Doadrio (2001).

\begin{tabular}{|c|c|c|c|c|}
\hline Common name & Scientific name & Family & Piscivory & $\begin{array}{l}\text { Number of } \\
\text { countries } \\
\text { introduced }\end{array}$ \\
\hline Siberian sturgeon $\dagger$ & Acipenser baeri & Acipenseridae & no & 4 \\
\hline Sterlet & Acipenser ruthenus & Acipenseridae & no & 4 \\
\hline Lake trout & Salvelinus namaycush & Salmonidae & yes & 9 \\
\hline Bighead carp & Aristichthys nobilis & Cyprinidae & no & 52 \\
\hline Grass carp $\dagger$ & Ctenopharyngodon idella & Cyprinidae & no & 80 \\
\hline Silver carp & Hypophthalmichthys molitrix & Cyprinidae & no & 65 \\
\hline Topmouth gudgeon $\dagger$ & Pseudorasbora parva & Cyprinidae & no & 29 \\
\hline Ide & Leuciscus idus & Cyprinidae & yes & 5 \\
\hline Albanian roach & Pachychilon pictus & Cyprinidae & yes & 2 \\
\hline Vimba & Vimba vimba & Cyprinidae & no & 2 \\
\hline Crucian carp & Carassius carassius & Cyprinidae & no & 16 \\
\hline Prussian carp & Carassius gibelio & Cyprinidae & no & 5 \\
\hline Fathead minnow & Pimephales promelas & Cyprinidae & no & 5 \\
\hline Rock bass & Ambloplites rupestris & Centrarchidae & yes & 3 \\
\hline Eastern mudminnow & Umbra pygmaea & Umbridae & no & 5 \\
\hline Ruffe & Gymnocephalus cernuus & Percidae & no & 3 \\
\hline
\end{tabular}

† Species detected in Iberian waters since 2001.

reported by Rahel (2000) for the continental United States (7.2\%) and Taylor (2004) for Canadian provinces (1.2\%). As in California, none of the 45 pairwise comparisons among Iberian basins produced overall negative results (i.e., biotic differentiation) (see Fig. 3A). The Iberian Peninsula and California share important abiotic and biotic features that may explain their similar patterns of biotic homogenization. Both regions predominantly feature a Mediterranean climate, are strongly isolated from other regions, have distinct fish faunas within regions, and original fish faunas have a relatively low number of species but many endemic taxa (Doadrio 2001, Moyle 2002). Also in both regions the proliferation of introduced species has been linked to aquatic habitat alterations (e.g., dams) (Clavero et al. 2004, Marchetti et al. 2004a).

The detected homogenization pattern fits well the predictions of a scenario in which there are no extirpations and the same species are introduced in different regions (Olden and Poff 2003). However, the analysis of the temporal variation in biotic homogenization among Iberian basins shows that this is a temporally dynamic process. When changes in similarity are studied at finer temporal scales, the continuing addition of new introduced species in certain basins leads towards biotic differentiation, while the expansion of previously introduced species produces an increasing biotic homogenization. As the temporal extent of observations increases, this differentiation-homogenization equilibrium is broken by the spread of previously introduced nonnative species.

It has already been noted that spatial scale has important influences in the perception of biotic homogenization (Marchetti et al. 2001, Taylor 2004). In general, small spatial grain increases the probability of observing the introduction or extinction of different species, resulting in the perception of biotic differentiation, since at this finer resolution habitat and commu- nity differences become more apparent (Olden and Poff 2004). In a similar way, our data show that reducing the temporal grain increases the probability of observing biotic differentiation, by reducing the probability of observing extinction events or (as in the case of Iberian fishes example) the spread of recently introduced species. This influence of the temporal scale of observation in the perception of biotic homogenization had been previously suggested by Olden and Poff (2003), but it had not been demonstrated. The fact that the temporal extent covered by the data strongly determines the changes in

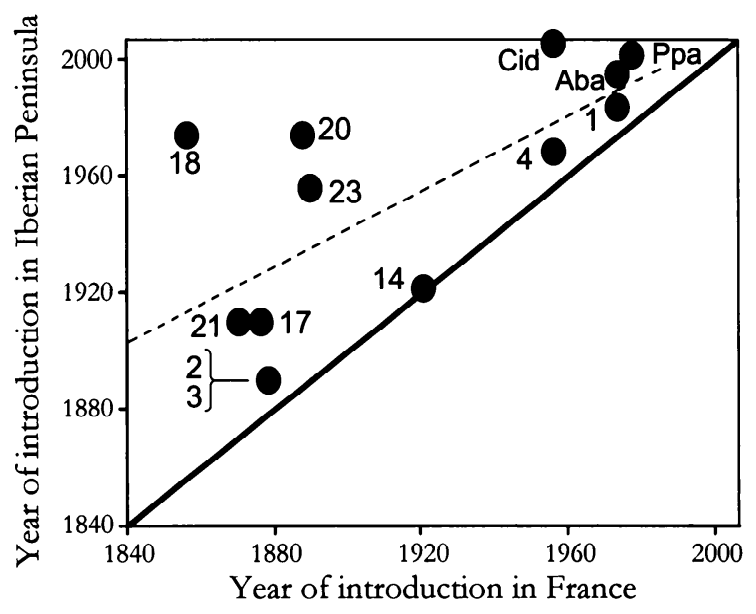

FIG. 6. Dates of introduction in the Iberian Peninsula plotted against those in France for fish species that have been introduced in both areas. The dashed line represents the regression line, while the solid line represents simultaneous introductions. To facilitate interpretation, ancient introductions were not plotted: carp (Cyprinus carpio) and goldfish (Carassius auratus) were introduced to France around 1300 and 1611, respectively, and to the Iberian Peninsula around 1650 in both cases. Species code numbers are as in Table 1 . Recent introductions included in Table 2 but not in Table 1: Aba, Acipenser baeri; Ppa, Pseudorasbora parva; Cid, Ctenopharyngodon idella. 
the similarity of communities has important implications for homogenization studies, in particular when comparing homogenization rates across regions. As stated above, most homogenization studies compare an original, pristine situation with the current one (but see Radomski and Goeman [1995] and Rooney et al. [2004] for exceptions with lake fish and forest plants, respectively). Our results indicate caution in making direct comparisons of homogenization results obtained using different temporal resolutions.

\section{Introduction and expansion routes}

The main source of variation of nonnative fish assemblages in the IP was a latitudinal gradient in species composition related to the proximity to France (donor region). This geographical structure shows that once an introduced species has become established in a certain basin, its expansion is not spatially haphazard but directed toward neighboring basins, resulting in a spatially clustered distribution of introduced fish species that allows the identification of routes for introduction and expansion. The analysis that included native species did not show these routes because historical biogeographical patterns dominated. On the other hand, introduced game species scored significantly toward the northern extreme of the latitudinal gradient defined by the CA, while piscivores were overrepresented among nonnative fish species present both in the IP and France. The same overrepresentation was not observed for game species. This was probably due to the fact that many small- and medium-sized cyprinids introduced in the IP, which have often been introduced as bait and forage fish (e.g., bleak, Alburnus alburnus [Elvira and Almodóvar 2001]), are native to France. The positive relationship between latitude and the amount of money spent on fishing licenses in Spain illustrates the importance of sport fishing activities and the establishment of nonnative game fish. In fact, the introduction of species for recreational freshwater fisheries is a global phenomenon that has produced great negative impacts on native fish faunas (Cambray 2003).

The original freshwater fish faunas in Iberian basins closer to France were more similar to those in French basins. After several introductions of nonnative species, Iberian and French fish faunas have experienced a clear biotic homogenization process. However, the resulting nonnative assemblages in Iberian basins are not equally similar to those present in France. Our results show that northeastern Iberian basins are more similar to French rivers than to the rest of Iberian basins in terms of specific composition of introduced fish faunas. This fact, together with the observed differences in introduction dates, demonstrates the existence of an introduction pathway from France to the IP, through northeastern Iberian basins. García-Berthou et al. (2005) had previously identified an introduction pathway from France to Spain and from Spain to Portugal using data from the FAO's Database of Invasive Aquatic Species (available online) ${ }^{2}$ This database contains information about species introduction events (e.g., countries of origin and destination), in contrast with our data, which only dealt with introduced species' distributions and features. The analyses presented here allow a more precise definition of the France-IP corridor, and at the same time suggest which new species are to be expected as invaders coming from France.

There are several examples that fit the proposed introduction and expansion patterns. One example is the case of the zander (Sander lucioperca), which was introduced in the 1970s in the Muga river basin (Catalonia), detected in the Ebro in the 1990s, later in the Douro, Tagus, and Júcar basins (Doadrio 2001), and more recently in the South basin (Miñano et al. 2002). The European catfish (Silurus glanis) was also introduced in the Ebro in the 1970s and nowadays can be found in Catalonian and Tagus basins (Doadrio 2001, Carol et al. 2003). Both species had been previously introduced to France (Keith and Allardi 2001) and are piscivorous species highly sought by anglers.

Our results suggest that fish species that are present as nonnatives in France and not yet recorded in the IP are the most likely to be introduced (Table 2). From this group, the most probable new introductions would involve piscivorous or globally widespread introduced species. Since the main introduction route in the IP is through northeastern basins, it can also be predicted that new introduced species will appear first in these basins. In agreement with these predictions, at least four fish species have been introduced to the IP after 2000 (last sampling year of Doadrio 2001): the topmouth gudgeon (Pseudorasbora parva) (Caiola and de Sostoa 2002), the grass carp (Ctenopharyngodon idella) (J. M. Queral, personal communication), the Siberian sturgeon (Acipenser baeri) (Elvira and Almodóvar 2001), and the bream (Abramis brama) (Benejam et al. 2005). These four species are present in France and have been introduced to northeastern Spain (Ebro or Catalonian basins). The first three species are also not native to France (Table 2), and the first two are widely introduced species worldwide. If these species are successful in establishing thriving populations, which is plausible due to their strong invasive character (Welcomme 1992), it can be predicted that they will expand their ranges to neighboring basins in the future.

This study exemplifies the idea that potential fish invaders can be predicted by identifying introduction routes, and that these can be efficiently detected by a simultaneous characterization of nonnative species and their distribution patterns. Results also show that the expansion of newly introduced species follows spatially predictable pathways. This information should help to establish useful policy tools in order to impede new introductions and limit the expansion of already

${ }^{2}\langle$ http://www.fao.org/fi/dias.htm $\rangle$ 
introduced species. Finally, our analytical approach might also be used in different geographic areas or with other taxonomic groups to predict invaders and introduction routes.

\section{ACKNOWLEDGMENTS}

We thank K. D. Fausch and anonymous reviewers for helpful comments that improved earlier versions of the manuscript. This study was financially supported by the Spanish Ministry of Science and Technology (REN200300477) and the Ministry of Universities, Research and Information Society (DURSI), Government of Catalonia (Catalan Government Distinction Award for university research 2004 to E. García-Berthou).

\section{Literature Cited}

$\rightarrow$ Alcaraz, C., A. Vila-Gispert, and E. García-Berthou. 2005. Profiling invasive fish species: the importance of phylogeny and human use. Diversity and Distributions 11:289-298.

Ambrosio, L. 2001. Metodología empleada para la realización del atlas de los peces continentales españoles. Pages 93-98 in I. Doadrio, editor. Atlas y libro rojo de los peces continentales de España. Ministerio de Medio Ambiente, Madrid, Spain.

Benejam, L., J. Carol, C. Alcaraz, and E. García-Berthou. 2005. First record of the common bream (Abramis brama) introduced to the Iberian Peninsula. Limnetica 24:273-274.

Bruslé, J., and J. P. Quignard. 2001. Biologie des poissons d'eau douce européens. Editions Technique et Documentation, Paris, France.

Caiola, N., and A. de Sostoa. 2002. First record of the Asiatic cyprinid Pseudorasbora parva in the Iberian Peninsula. Journal of Fish Biology 61:1058-1060.

Cambray, J. A. 2003. Impact on indigenous species biodiversity caused by the globalisation of alien recreational freshwater fisheries. Hydrobiologia 500:217-230.

Carol, J., L. Benejam, Q. Pou-Rovira, L. Zamora, and E. García-Berthou. 2003. First record of white bream (Abramis bjoerkna) in Catalonia (Spain) and new introductions of exotic fish (Alburnus alburnus, Sander lucioperca and Silurus glanis) into Catalan river basins. [In Catalan.] Butlletí de la Institució Catalana d'Història Natural 71:135-136.

Clavero, M., F. Blanco-Garrido, and J. Prenda. 2004. Fish fauna in Iberian Mediterranean river basins: biodiversity, introduced species and damming impacts. Aquatic Conservation: Marine and Freshwater Ecosystems 15:415-426.

Clavero, M., and E. García-Berthou. 2005. Invasive species are a leading cause of animal extinctions. Trends in Ecology and Evolution 20:110.

Copp, G. H., et al. 2005. To be, or not to be, a nonnative freshwater fish? Journal of Applied Ichthyology 21:242-262.

Doadrio, I., editor. 2001. Atlas y libro rojo de los peces continentales de España. Ministerio de Medio Ambiente, Madrid, Spain.

Doadrio, I., B. Elvira, and Y. Bernat. 1991. Peces continentales españoles. Inventario y clasificación de zonas fluviales. ICONA, Ministerio de Agricultura, Pesca y Alimentación, Madrid, Spain.

Ehrlich, P. R., and A. H. Ehrlich. 1992. The value o $\rightarrow$ biodiversity. Ambio 21:219-226.

Elton, C. S. 1958. The ecology of invasions by animals and plants. Methuen, London, UK.

Elvira, B. 1995. Native and exotic freshwater fishes in Spanish river basins. Freshwater Biology 33:103-108.

Elvira, B., and A. Almodóvar. 2001. Freshwater fish introduc $\rightarrow$ tions in Spain: facts and figures at the beginning of the 21 st century. Journal of Fish Biology 59:323-331.

Froese, R., and D. Pauly, editors. 2006. FishBase. $\langle w w w . f i s h b a s e . o r g\rangle$
García-Berthou, E. 2001. On the misuse of residuals in ecology: testing regression residuals vs. the analysis of covariance. Journal of Animal Ecology 70:708-711.

García-Berthou, E., C. Alcaraz, Q. Pou-Rovira, L. Zamora, G. Coenders, and C. Feo. 2005. Introduction pathways and establishment rates of invasive aquatic species in Europe. Canadian Journal of Fisheries and Aquatic Sciences 65:453463.

Garcia-Berthou, E., and R. Moreno-Amich. 2000. Introduction of exotic fish into a Mediterranean lake over a 90-year period. Archiv für Hydrobiologie 149:271-284.

Jongman, R. H. G., C. J. F. ter Braak, and O. F. R. Van Tongeren. 1995. Data analysis in community and landscape ecology. Second edition. Cambridge University Press, Cambridge, UK

Keith, P., and J. Allardi, editors. 2001. Atlas des poissons d'eau douce de France. Patrimoines naturels, 47. Muséum National d'Histoire Naturelle, Paris, France.

Kolar, C. S., and D. M. Lodge. 2001. Progress in invasion biology: predicting invaders. Trends in Ecology and Evolution 16:199-204.

Lockwood, J. L., and M. L. McKinney, editors. 2001. Biotic homogenization. Kluwer Academic, New York, New York, USA.

$\rightarrow$ Mack, R. N., D. Simberloff, W. M. Lonsdale, H. Evans, M. Clout, and F. A. Bazzaz. 2000. Biotic invasions: causes, epidemiology, global consequences, and control. Ecological Applications 10:689-710.

MAPA. 2003. Anuario de estadistica agroalimentaria. Ministerio de Agricultura, Pesca y Alimentación, Madrid, Spain.

Marchetti, M. P., T. Light, J. Feliciano, T. Armstrong, Z. Hogan, J. Viers, and P. B. Moyle. 2001. Homogenization of California's fish fauna through abiotic change. Pages 259278 in J. L. Lockwood and M. L. McKinney, editors. Biotic homogenization. Kluwer Academic/Plenum, New York, New York, USA.

$\rightarrow$ Marchetti, M. P., T. Light, P. B. Moyle, and J. H. Viers. $2004 a$. Fish invasions in California watersheds: testing hypotheses using landscape patterns. Ecological Applications 14:15071525 .

Marchetti, M. P., J. L. Lockwood, and T. Light. 2006. Effects of urbanization on California's fish diversity: differentiation, homogenization and the influence of spatial scale. Biological Conservation 127:310-318.

Marchetti, M. P., P. B. Moyle, and R. Levine. 2004b. Invasive species profiling? Exploring the characteristics of nonnative fishes across invasion stages in California. Freshwater Biology 49:646-661.

McKinney, M. L., and J. L. Lockwood. 1999. Biotic homogenization: a few winners replacing many losers in the next mass extinction. Trends in Ecology and Evolution 14: 450-453.

Miñano, P. A., F. J. Oliva-Paterna, and M. Torralva. 2002. First record of Sander lucioperca (L.) (Actinopterygii, Percidae) in the Segura River basin, SE Spain. [In Spanish.] Anales de Biología 24:77-79.

Moyle, P. B. 2002. Inland fishes of California. Revised and expanded. University of California Press, Berkeley, California, USA.

Olden, J. D., and N. L. Poff. 2003. Toward a mechanistic understanding and prediction of biotic homogenization. American Naturalist 162:442-460.

$\rightarrow$ Olden, J. D., and N. L. Poff. 2004. Ecological processes driving biotic homogenization: testing a mechanistic model using fish faunas. Ecology 85:1867-1875.

Olden, J. D., and T. P. Rooney. 2006. On defining and quantifying biotic homogenization. Global Ecology and Biogeography 15:113-120.

Radomski, P. J., and T. J. Goeman. 1995. The homogenizing of Minnesota lake fish assemblages. Fisheries 20:20-23. 
Rahel, F. J. 2000. Homogenization of fish faunas across the United States. Science 288:854-856.

$\rightarrow$ Ricciardi, A., and H. J. MacIsaac. 2000. Recent mass invasion of the North American Great Lakes by Ponto-Caspian species. Trends in Ecology and Evolution 15:62-65.

$\rightarrow$ Rooney, T. P., S. M. Wiegmann, D. A. Rogers, and D. M. Waller. 2004. Biotic impoverishment and homogenization in unfragmented forest understory communities. Conservation Biology 18:787-798.

Ruiz, G. M., and J. T. Carlton, editors. 2003. Invasive species: vectors and management strategies. Island Press, Washington, D.C., USA.

Shea, K., and P. Chesson. 2002. Community ecology theory as a framework for biological invasions. Trends in Ecology and Evolution 17:170-176.

SPSS. 2002. SPSS version 11.5. SPSS, Chicago, Illinois, USA.
Taylor, E. B. 2004. An analysis of homogenization and differentiation of Canadian freshwater fish faunas with an emphasis on British Columbia. Canadian Journal of Fisheries and Aquatic Sciences 61:68-79.

$\rightarrow$ Vargas, J. M., R. Real, and J. C. Guerrero. 1998. Biogeographical regions of the Iberian Peninsula based on freshwater fish and amphibian distributions. Ecography 21: 371-382.

Vitousek, P. M., H. A. Mooney, J. Lubchenco, and J. M. Melillo. 1997. Human domination of Earth's ecosystems. Science 277:494-499.

Welcomme, R. L. 1992. A history of international introductions of inland aquatic species. ICES Marine Science Symposia 194:3-14.

Williamson, M. 1996. Biological invasions. Chapman and Hall, London, UK. 